\title{
NUEVOS DIBUJOS Y DOS LIENZOS INÉDITOS DE CLAUDIO COELLO
}

\author{
Teresa Zapata Fernández de la Hoz y Juan Carlos Gómez Aragüete
}

\begin{abstract}
Artista de amplísimos recursos, siempre apreciado y citado con elogios, Claudio Coello (1642-1693) es sin duda la gran figura de la pintura española de la segunda mitad del siglo XVII. En este artículo se atribuyen al pintor un grupo de dibujos conservados en la Casa de la Moneda de Madrid y en los Uffizi, algunos preparatorios para obras seguras, a los que se añaden dos pinturas inéditas, entre ellas un espléndido retrato de un religioso.
\end{abstract}

Palabras clave: Dibujos; Casa de la Moneda; Uffizi; Pinturas; Retrato.

\section{NEW DRAWINGS AND TWO UNPUBLISHED PAINTINGS BY CLAUDIO COELLO}

Artist of great resources, always appreciated and cited with praise, Claudio Coello (1642-1693) is undoubtedly the great figure of Spanish painting in the second half of the seventeenth century. In this article a group of drawings preserved in the Madrid Casa de la Moneda (Mint) and the Uffizi in Florence are attributed to the painter. Some of them are preparatory studies for secure works. Likewise presented are two unpublished paintings, one of them a splendid portrait of a member of a religious order.

Key words: Drawings; Casa de la Moneda (Mint); Uffizi; Paintings; Portrait.

Claudio Coello es uno de los pocos pintores de la llamada "Escuela madrileña" que pertenecen a ella no solo por razones artísticas, sino también por su lugar de nacimiento ${ }^{1}$. Nacido en 1642, se formó en el taller de Francisco Rizi, de quien heredó su estilo dinámico y emotivo, que supo combinar con el de los pintores italianos y flamencos presentes en las colecciones reales, a las que tuvo acceso a través de su amistad con Carreño de Miranda ${ }^{2}$ y, más tarde, en calidad de pintor del rey ${ }^{3} \mathrm{y}$

\footnotetext{
${ }^{1}$ Para la bibliografía sobre el pintor hasta 1989, véase SULLIVAN, 1989: 317-339, y NiCOLAU CASTRO, que no recoge Sullivan. Para la posterior, Gutiérrez Pastor, 2003: 142, y además, Lamas Delgado; Aterido, 2007; Gómez Jara; VÉliz; Zapata y PÉrez Hernández.

2 Palomino dice que "[...] tomó Claudio gran amistad con Carreño, el cual con la ocasión de Pintor de cámara, le permitió copiar en Palacio muchos originales de Ticiano, Rubens y Van-Dick, y otros" (PALOMino, 1947: 1060).

${ }^{3}$ Nombrado el 30 de marzo de 1683, en el puesto de Dionisio Mantuano (Sullivan, 1989: 307).
} 
de cámara ${ }^{4}$ de Carlos II. Su obra maestra, La adoración de la Sagrada Forma de Gorkum, de la sacristía de la iglesia del Escorial, comenzada por su maestro, quien recibió el encargo unos meses antes de morir, es un alarde de virtuosismo y dominio de la "perspectiva aérea", además de una espléndida galería de retratos, y constituye uno de los grandes logros de la pintura española.

Con este artículo queremos contribuir al mejor conocimiento de la obra del gran pintor madrileño, en esta ocasión en su faceta de dibujante, a la que se suman dos pinturas, entre ellas un magnifico retrato, género del que se conoce poco, teniendo en cuenta su condición de pintor real.

\section{Dibujos}

En primer lugar, nos vamos a referir a una serie de dibujos conservados en el Museo Casa de la Moneda de Madrid, clasificados en el catálogo del museo como anónimos madrileños del siglo XVII.

El primero, titulado Hombre llevando una tiara ${ }^{5}$ (fig. 1), es obra segura de Claudio Coello, pues se trata de un estudio preparatorio para la figura principal del lienzo del ático del retablo de Santa Gertrudis, en la iglesia del convento de San Plácido de Madrid, identificado hasta ahora como San Benito rechazando la tiara ${ }^{6}$ o Renuencia de San Gregorio Magno a aceptar el papado ${ }^{7}$ (fig. 2).

Sin embargo, la escena del cuadro no se ajusta a ninguno de los dos episodios -en el caso de San Benito, nunca alcanzó la tiara papal; en el de San Gregorio, su rechazo fue antes de que se le llegara a nombrar-, mientras que coincide con lo que se conoce como "la gran renuncia", $L a$ renuncia de San Pedro Celestino al pontificado ${ }^{8}$.

El anacoreta Pedro de Morrone, natural de los Abruzos (Italia), animado por sus numerosos seguidores, marchó a Roma a recibir el sacerdocio, de donde regresó a su vida ascética en el monte que le diera su nombre. La fama de santidad y sus milagros llevaron a muchos a solicitarle ser sus discípulos, lo que le llevó a fundar en 1254 una orden, llamada después Orden de los monjes celestinos en honor a su fundador, considerada como una derivación de la Orden de los benedictinos, con normas más estrictas. Cuando la orden se fue extendiendo, Morrone la dejó en manos de un vicario para dedicarse a las prácticas ascéticas. En 1294, ya anciano, recibió la inesperada visita del arzobispo de Lyon y los demás prelados del cónclave, quienes le comunicaron que había sido elegido Papa ${ }^{9}$. Sumamente sorprendido, al final cedió a los designios celestiales y aceptó el cargo, con el nombre de Celestino V. Sin embargo, su carácter solitario, su desconocimiento de las cosas mundanas, las intrigas y ambiciones de la corte papal, en particular del futuro Bonifacio VIII, pronto le llevaron a renunciar solemnemente al más alto cargo de la Iglesia Católica. El 12 de diciembre de 1294, seis meses después de su nombramiento, tuvo lugar "la gran renuncia”, hecho insólito en la historia del papado ${ }^{10}$.

\footnotetext{
4 Juró el cargo el 31 de diciembre de 1685, ocupando el puesto dejado vacante por la muerte de Carreño de Miranda (SULLIVAN, 1989: 308).

5 Durán, 1980: 79 y 189, núm. 106. Carboncillo sobre papel agarbanzado. $286 \times 170 \mathrm{~mm}$. En el reverso, estudio de la figura con el hábito.

6 GAYA NUÑO, 1957: 33.

7 Sullivan, 1989: 176.

8 Colorado (COLORADO, 1992: 22) identificó correctamente el santo, pero no la escena, que, según él, "plasma el momento en que el Santo [...] rehúsa hacerse cargo de la rica tiara que le ofrece un purpurado".

${ }^{9}$ Habían transcurrido 27 meses desde la muerte de Nicolás IV, y las intrigas, diferencias y los numerosos bandos entre los miembros del colegio cardenalicio, habían imposibilitado la designación de un sucesor.

${ }_{10} \mathrm{Su}$ sucesor, Bonifacio VIII, por miedo a un cisma, no le dejó regresar a su antiguo lugar y le encerró en el Monte Fumone, junto a Anagni, donde continuó con su vida de soledad, oración y penitencia, hasta su muerte en 1296.
} 
Fig. 1. Claudio Coello. Hombre llevando una tiara. Museo Casa de la Moneda, Madrid.
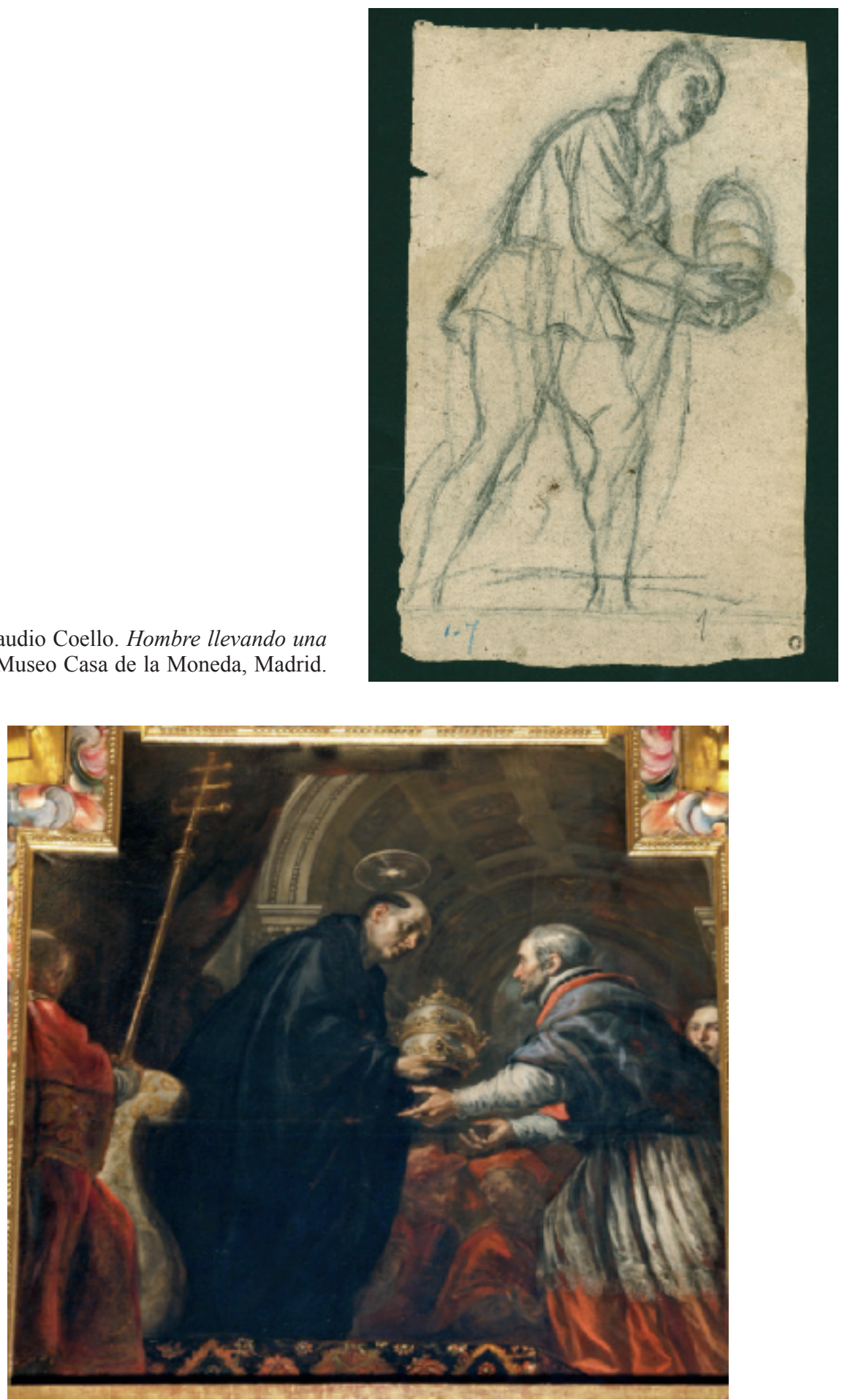

Fig. 2. Claudio Coello. La renuncia de San Pedro Celestino al pontificado. Iglesia del convento de San Plácido, Madrid.

Arch. esp. arte, LXXXVII, 347, JULIO-SEPTIEMBRE 2014, 227-244

ISSN: 0004-0428, eISSN: 1988-8511, doi: 10.3989/aearte.2014.15 
El jesuita Pedro de Ribadeneyra (1526-1611), en su célebre y difundido libro Flos Sanctorum, describe así este episodio de la vida de San Pedro Celestino:

[...] hizo luego solemnissima renunciacion, del Pontificado el dia antes de Santa Lucia á doce de Diciembre del mismo año de mil doscientos noventa, y quatro, haviendolo tenido solo seis meses, y dió libre facultad á los Cardenales, que pudiessen elegir Pontifice a su voluntad: y dexando las insignias Pontificales con mas contento, que ninguno jamás las tomó; el que era Papa, y Sumo Pastor de todos, baxando de la Silla Apostolica de San Pedro, para subir mas seguramente á la del Cielo, se postró como un pobre Monge á los pies, de los que poco antes eran sus ovejas, con admiración, y espanto de todos. ${ }^{11}$

Claudio Coello ha imaginado la escena sobre una tarima ricamente alfombrada, levantada delante de un arco desde el que se abre una suntuosa galería cubierta con bóveda de cañón decorada con casetones. En el centro, Celestino, vestido con el humilde hábito benedictino, entrega la tiara a un purpurado. A la izquierda, en primer plano, cerrando la composición por ese lado, un acólito con una rica capa pluvial, visto a contraluz -a modo de repoussoir, como en otras obras del pintor-, sostiene la cruz papal, cuya diagonal subraya la que señala la postura del santo. Bajo las dos figuras principales, pero en un plano inferior, vemos otros dos personajes de medio cuerpo, sin duda miembros del colegio cardenalicio, que comentan la insólita escena.

El pintor se ha situado en el suelo de la estancia, a la altura del resto de los asistentes a la ceremonia, que se desarrolla en la tarima, cuyo recuerdo de los tablados para representaciones teatrales u otros actos religiosos en Madrid durante el siglo XVII se acentúa con el gran cortinón de la izquierda, levantado a hurtadillas por unos monjes. Sorprende el rostro del personaje que sobresale por encima de la espalda del cardenal y mira con fijeza la escena, cuyas facciones se nos muestran con total claridad, probablemente un autorretrato ${ }^{12}$.

El lienzo destaca por su bellísimo colorido, en el que el pintor juega con diferentes tonalidades de rojos, con los que consigue transmitir las diferentes calidades de las telas de los personajes: pardusco en el gran cortinón, anaranjado para la seda o raso de los cardenales y bermellón para la dalmática del acólito, que contrastan con la muceta de color violeta del cardenal que recibe la tiara.

En cuanto al tema y la iconografía, nada frecuentes en la pintura española, le serían proporcionadas seguramente por el responsable del programa iconográfico de San Plácido, cuya identidad se desconoce, tomada de alguna fuente de la orden más explícita ${ }^{13}$.

En 1313, el Papa Clemente V lo elevó a los altares en Avignon. Los dos grandes poetas italianos Dante y Petrarca se refirieron a este suceso con opiniones opuestas: mientras Dante lo condenó en el Infierno (Divina Comedia, canto III), Petrarca defendió su profunda espiritualidad, que le hubiera impedido atender los deberes del papado (De vita solitaria, III, 27).

11 Ribadeneyra, 1790: 126.

12 Hasta la fecha sólo se conoce un autorretrato seguro de Coello, el pintado en 1685 en los frescos de "La Mantería" de Zaragoza, a los que nos referiremos más adelante. Recientemente se ha identificado otro, que el artista incluyó en su obra maestra, La adoración de la Sagrada Forma de Gorkum, al lado del retrato de su maestro Francisco Rizi (ATERIDO, 2007: 511-512, fig. 2). Aunque el rostro de Coello, situado en segundo plano a la izquierda, está en penumbra, se pueden advertir las semejanzas con el del lienzo de San Plácido. Sullivan, creemos que con acierto, sugiere que el personaje del cuadro de Cristo y Santa María Magdalena en casa de Simón el Fariseo situado al fondo, detrás de los apóstoles, que mira al espectador con una jarra en alto, se trate de un autorretrato (Sullivan, 1989: 192-193).

${ }^{13}$ En el Consejo de Estado, depositado por el Museo del Prado, se conserva una pintura de San Pedro Celestino, un retrato de cuerpo entero pintado por Bartolomé Román (h. 1585-1647), que forma parte de una serie de venerables benedictinos, con la tiara y el báculo papales depositados en el suelo, acompañado de una cartela con la siguiente inscripción: "No Pe S PEDRO CELESTINO QUE RENUN' EL PONTIFICADO". Núm. de catálogo P03346. Véase ANGULO Y PÉrez SÁNCHEZ, 1983: 323, lám. 311 
El siguiente dibujo, Cabeza de hombre joven ${ }^{14}$ (fig. 3), se puede considerar como un estudio preparatorio para la cabeza de San Bernardo del cuadro de El milagro de la lactancia o Premio lácteo a San Bernardo de la colección Granados de Madrid $^{15}$. Se trata de una de las obras del periodo central de su carrera, alrededor de 1675-80, en el que los temas religiosos alcanzan su mayor delicadeza y misticismo. La expresión de sincera devoción y agradecimiento del rostro del fundador de los cistercienses al auxilio de la Virgen, adquiere una veracidad pocas veces alcanzada en la pintura española del momento, a la que corresponde este dibujo de la Casa de la Moneda, cuya semejanza con el rostro del santo es evidente. A todo ello hay que sumar la circunstancia de que, en el reverso, están dibujadas cuatro cabezas de angelitos, modelos que, con alguna variante, el pintor madrileño ha empleado en el lienzo.

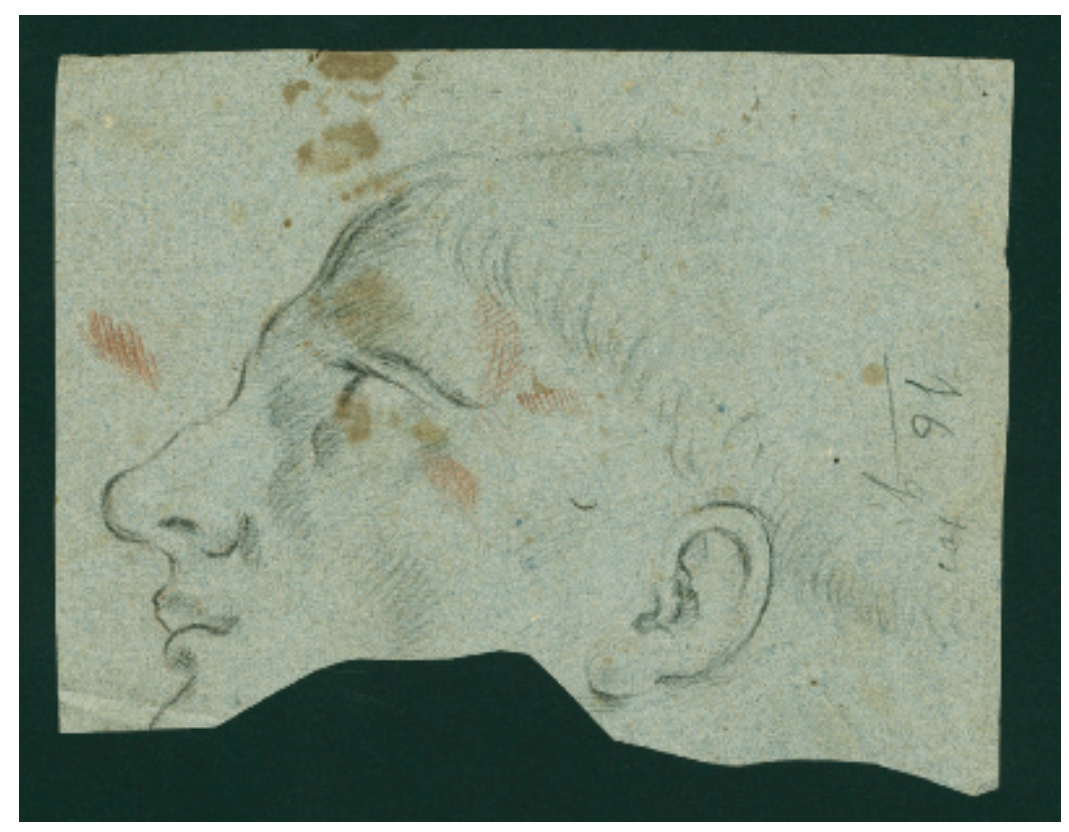

Fig. 3. Claudio Coello. Cabeza de hombre joven. Museo Casa de la Moneda, Madrid.

Bernardo de Claraval fue uno de los más fervientes difusores del culto de la Virgen, y bajo su iniciativa todas las iglesias del Císter estaban bajo la advocación mariana ${ }^{16}$. La Virgen no sólo se le apareció, como a otros santos, sino que le distinguió cuando en una ocasión, en la que rezaba ante una estatua de la Virgen amamantando al Niño, pronunció las palabras monstra te esse Matrem (demuestra que eres Madre); del pecho de María saltaron entonces algunas gotas de le-

14 DurÁn, 1980: 81 y 198, núm. 114. Lápiz negro y sanguina sobre papel gris verdoso. $150 \times 206 \mathrm{~mm}$.

15 Reproducido en Pérez SÁnchez, 1990: 140, fig. 5 y Brown, 2010: 48. Mide $182 \times 120 \mathrm{~cm}$. La colección del pintor Miguel Granados Pérez (colección Granados) está considerada como una de las más ricas, singulares y rigurosas colecciones de arte español, pintura y escultura, del siglo XVII y parte del XVIII. Cuenta con obras de Alonso Cano, Zurbarán, Murillo, Valdés Leal, Claudio Coello, Carreño de Miranda y otros grandes maestros del barroco.

16 Sobre su historia e iconografía, véase RÉAU, 2001: 213 y ss. 
che, que le humedecieron los labios. La leyenda, conocida como Lactatio Bernardi, se popularizó durante la Contrarreforma, en particular en España, Países Bajos y Alemania ${ }^{17}$.

Los dos siguientes dibujos pueden relacionarse con el ciclo de frescos de la iglesia del antiguo Colegio Imperial de Madrid de los jesuitas, más tarde catedral de San Isidro, uno de los más ambiciosos ciclos decorativos llevados a cabo por Coello, junto con su amigo y compañero José Donoso (h.1628/32-1690) ${ }^{18}$. Ambos artistas decoraron la capilla de San Ignacio, llamada de los Borjas, y la sacristía. Coello solo pintó también la cúpula de la capilla del Santo Cristo ${ }^{19}$.

En primer lugar, vamos a referirnos a la capilla de San Ignacio, con la que creemos que podría estar relacionado el primero de los dibujos, Figura elevada por ángeles ${ }^{20}$ (fig. 4), en concreto con la escena del Triunfo de San Ignacio, pintada, según Palomino, en "el cañón del cupulino" de dicha capilla.

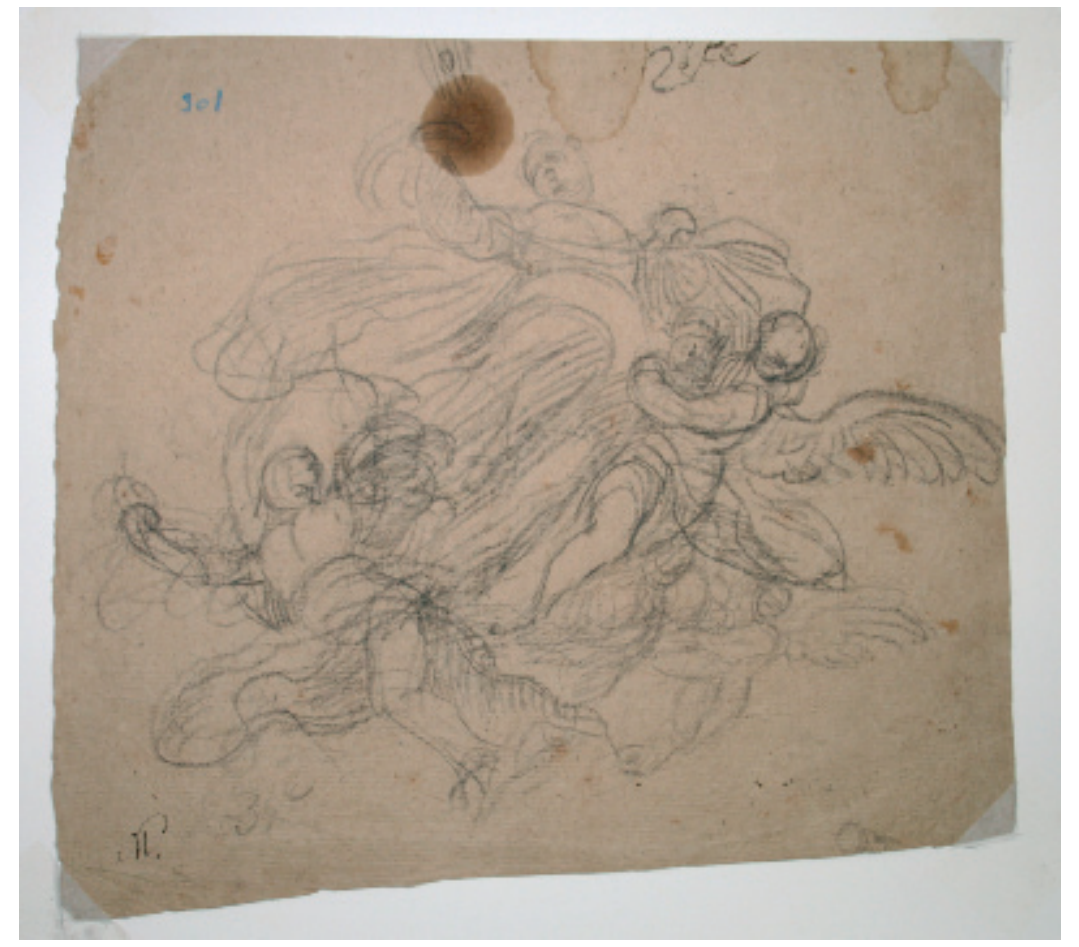

Fig. 4. Claudio Coello. Figura elevada por ángeles. Museo Casa de la Moneda, Madrid.

${ }^{17}$ En nuestro país destacan las obras de Juan de Roelas (Hospital de San Bernardo, Sevilla), Alonso Cano y Murillo (Museo del Prado), y Carreño de Miranda (Museo de Pastrana, Guadalajara, y Gran Residencia de Personas Mayores de Vista Alegre, Madrid).

18 Según Palomino, esta colaboración comenzó al regreso de Donoso de Italia, cuando decoraron el presbiterio de la iglesia de Santa Cruz de Madrid, hacia 1667-1668, colaboración que continuó en la sacristía de la catedral de Toledo, techo de la sala de Capitulo de la Cartuja del Paular, Colegio Imperial, Casa de la Panadería y techo o bóveda de la torre del cuarto de la Reina del Palacio (Palomino, 1947: 1060-1061). En la Vida de Donoso, Palomino cita además las pechinas de la iglesia del convento de los Basilios y las de la iglesia de la Santísima Trinidad (PALOMino, 1947: 1038).

19 Palomino, 1947: 1061. Sobre la capilla del Cristo, véase Aterido, 1998.

20 DuRÁN, 1980: 78 y 188, núm. 104. Lápiz negro sobre papel agarbanzado verjurado. $228 \times 262$ mm. 
La capilla, de planta ovalada, se construyó y decoró entre 1671-1673 con motivo de la canonización de San Francisco de Borja (1671), costeada por los Borjas de la casa de Esquilache. Según la descripción de Palomino, la bóveda la pintaron al fresco "con excelentes compartimientos de arquitecturas, bellísimos adornos, tocados de oro con gran gusto". Sobre las cuatro puertas representaron otras tantas historias de la vida de San Ignacio, y en los espacios intermedios, las cuatro partes del mundo, alegorías de la expansión universal de su doctrina. Coronaba la decoración el Triunfo de San Ignacio, pintado en la pared del cupulino, "el cañón del cupulino". Tormo, que alcanzó a ver la capilla antes de su destrucción en 1936, confirma la descripción de los frescos de la bóveda, que califica de "brillantes", ejecutados por "la tan acostumbrada colaboración" de José Donoso y Claudio Coello ${ }^{21}$. Por otra parte, una fotografía anterior a esa fecha, publicada por Angulo, ha hecho posible conocer parte de la capilla ${ }^{22}$.

El dibujo al que hemos hecho referencia, consideramos que es de mano del pintor, destinado a la decoración del cupulino, sobre la que creemos oportuno transcribir la descripción de Palomino:

Rematando el ornato de esta preciosa capilla, con el triunfo de este glorioso capitán de tan sagrada Compañía, llevado por ministerio de ángeles, a gozar del premio, que le merecieron sus heroicas empresas; lo cual está ejecutado en el cañón del cupulino de dicha capilla, con singularísimo primor, que desde abajo no se conoce, porque satisface a la vista, como debe. Pero desde arriba se ve la deformidad de pies, y piernas de los ángeles, para que degradando la vista oblicua aquellas cantidades, vengan a quedar desde abajo en debida proporción. ${ }^{23}$

Como podemos comprobar, Coello ha representado al santo en un violento escorzo ascensional, elevado por el impulso de dos ángeles adolescentes, en escorzos no menos atrevidos, con la mirada fija en un ostensorio que sostiene en alto con su mano derecha, junto a una filacteria cuyo extremo sujeta con la otra, destinada con toda probabilidad a mostrar la divisa de la orden: $A d$ Maiorem Dei Gloriam. Los dos ángeles podrían sostener otros dos símbolos distintivos del fundador de los jesuitas: un círculo con las siglas IHS rodeado de los rayos solares, emblema de la Compañía de Jesús, que parece sostener sobre su hombro izquierdo el ángel de la izquierda, y un corazón flamígero, que apretaría contra su pecho el ángel de la derecha.

El dorso del dibujo (fig. 5), un primer apunte o tanteo, vuelve a ser determinante para establecer su relación con la pintura, pues el pintor, al haber encuadrado la escena en la arquitectura real de la capilla, ha dibujado el borde inferior curvo del arranque del cupulino, sobre el que sitúa un pedestal o basa decorativa, en la que descansa una esfera - ¿el mundo?-, de la que surgen unas figuras, apenas esbozadas, sin duda los mismos ángeles del anverso.

De la decoración de la capilla se conserva un dibujo en los Uffizi de Florencia, identificado por Angulo como un estudio de la decoración definitiva ${ }^{24}$. El dibujo muestra la parte principal de la capilla, al fondo, destacada por el camarín de San Ignacio con su estatua sobre el altar ${ }^{25}$, y una parte del lado izquierdo de la misma. Sobre la puerta de acceso al camarín, un medallón con una escena de la vida del santo, en concreto, la Aparición de Jesús con la Cruz a cuestas al santo, cuando promete ayudarle en su misión ${ }^{26}$. A continuación, en una hornacina fingida, está

21 TORMO, 1985: 113.

22 Angulo, 1928: lám. B. La vuelve a publicar Pérez Sánchez, en Pérez SÁnchez, 1990: 154, fig. 16.

23 Palomino, 1947: 1060.

24 Angulo, 1928: 52; Sullivan, 1989: 247, D7.

${ }^{25}$ La estatua fue sustituida en el siglo XIX por la venerada imagen de la Soledad de Gaspar Becerra, procedente del convento de la Victoria de Madrid.

26 "Quando iba a Roma a fundar la Compañía, se le apareció con una luz clarísima Dios Padre, que encomendó a su Hijo, que venía con la Cruz a cuestas, al mismo San Ignacio, que estaba allí presente, y a sus compañeros: y bol-

Arch. esp. arte, LXXXVII, 347, JULIO-SEPTIEMBRE 2014, 227-244

ISSN: 0004-0428, eISSN: 1988-8511, doi: 10.3989/aearte.2014.15 


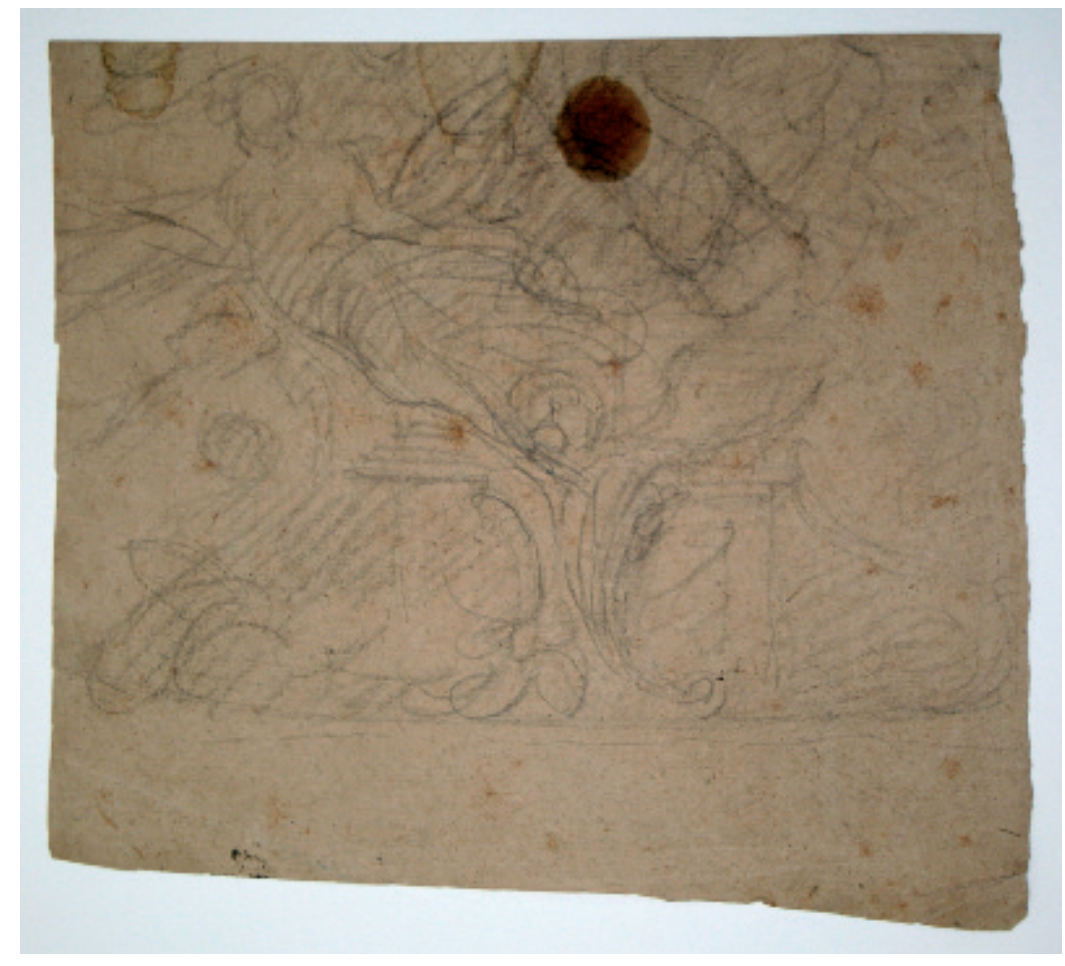

Fig. 5. Claudio Coello. Figura elevada por ángeles (reverso). Museo Casa de la Moneda, Madrid.

esbozada la alegoría de la Fe, con la cruz y el cáliz, sus atributos. Ménsulas, jarrones con flores, cabezas aladas, ángeles niños con guirnaldas de flores y otros elementos de bulto decoran la arquitectura; a la izquierda, una estatua de San Francisco de Borja contemplando la calavera ${ }^{27}$. Este primer proyecto fue modificado en la decoración definitiva, al sustituir las cuatro virtudes por las cuatro partes del mundo, una de las cuales, Asia, aparece en una fotografía publicada por Pérez Sánchez, con la cartela que la identifica a sus pies ${ }^{28}$.

Para el siguiente dibujo, Jesuita de rodillas ${ }^{29}$ (fig. 6), debemos centrarnos en la escena del medallón situado sobre el altar, la Aparición de Jesús con la Cruz a cuestas a San Ignacio, uno de los cuatro episodios de la vida del santo que decoraban la capilla, escena que, además, Coello volvió a pintar en el techo de la sacristía de la iglesia.

La sacristía, que ocupaba el cuerpo de la antigua iglesia de San Pedro y San Pablo Apóstoles, fue decorada también por José Donoso y Claudio Coello, quienes pintaron al fresco tres escenas en la bóveda y otra sobre la puerta de entrada, relativas a la vida y milagros de San Ignacio de Loyola y San Francisco Javier ${ }^{30}$. De la bóveda, la central -San Ignacio ante el Nazareno, según

\footnotetext{
viéndose Christo acia su siervo Ignacio, con rostro afable dixo: Yo os seré propicio, y favorable en Roma" (RIBADENEYRA, 1790: 389).

${ }^{27}$ Las otras tres estatuas eran las de San Estanislao de Kostka, San Juan Francisco de Regis y San Luis Gonzaga.

28 Pérez SÁnChez, 1990: 154, fig. 17.

29 Durán, 1980: 75-76 y 182, núm. 98. Lápiz negro, aguada gris, pluma con tinta marrón y toques de clarión sobre papel agarbanzado verjurado. $340 \times 273 \mathrm{~mm}$.

30 Palomino, 1947: 1060-1061 y Tormo, 1985: 115.
} 


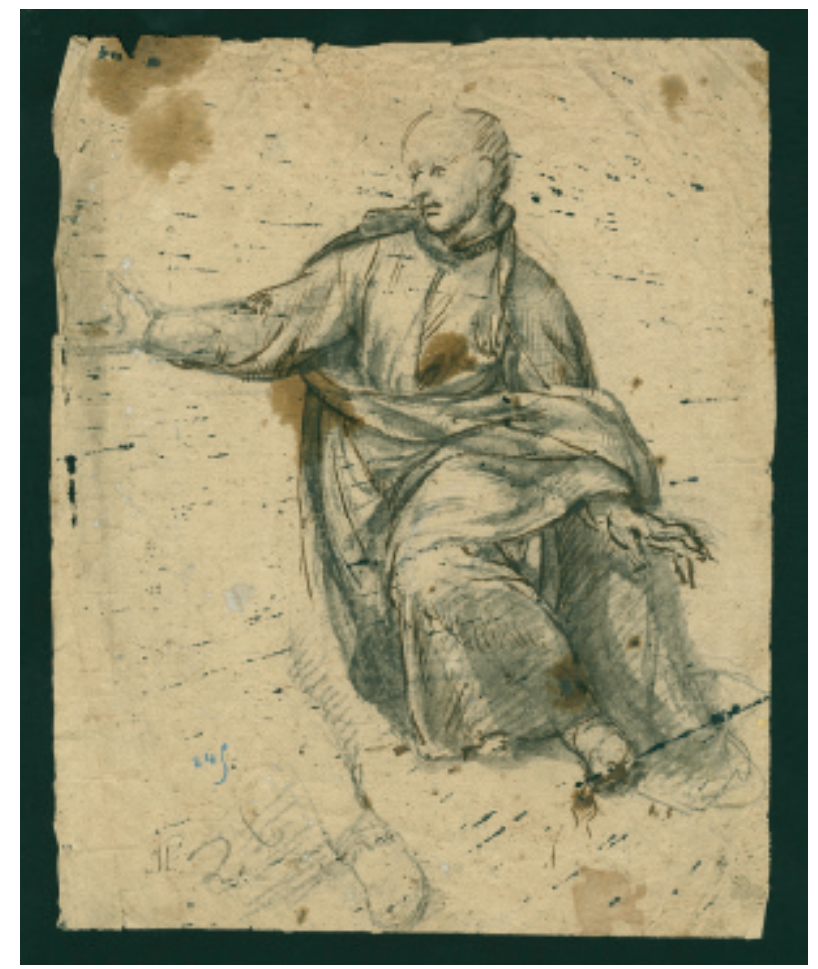

Fig. 6. Claudio Coello. Jesuita de rodillas. Museo Casa de la Moneda, Madrid.
Tormo $^{31}$ - era de Coello, mientras que las de los lados, cuyas historias desconocemos, eran de Donoso ${ }^{32}$. De Coello era también el fresco sobre la entrada ${ }^{33}$, Milagro de San Francisco Javier, única escena de la que se conserva una fotografía ${ }^{34}$.

El dibujo muestra a un jesuita, con el manteo recogido sobre el antebrazo izquierdo, semiarrodillado hacia su derecha y con los brazos levantados en actitud de admiración o asombro, para formar parte de una aparición divina o de un santo, como sugirió con acierto Reyes Durán ${ }^{35}$, ya que creemos que representa a San Ignacio de Loyola, en la escena de la Aparición de Cristo con la Cruz a cuestas al santo, que Coello representó en la capilla de San Ignacio y en la sacristía de la iglesia, como hemos indicado anteriormente.

La figura es similar a la de San Ignacio en la escena del medallón del dibujo de los Uffizi, excepto el punto de vista, que allí es más bajo. Sin embargo, en el fresco definitivo, que conocemos por la fotografía publicada por Angulo ${ }^{36}$, el pintor lo corrigió, elevándolo, con lo que la figura se aproximaría aun más a la del dibujo de la Casa de la Moneda. Por otra parte, el estilo guarda ciertas semejanzas con el de la escena del Milagro de San Francisco Javier, fresco pintado por Coello sobre la puerta de la sacristía, de la que se puede deducir que las figuras de esta pieza, en pro-

31 TORMO, 1985: 115

32 De Donoso eran también dos lienzos grandes, sobre la cajonera: San Francisco Javier dando la Comunión y San Ignacio celebrando misa (PALOMINo, 1947: 1037 y 1061; PonZ, 1793: 93 y Tormo, 1985: 115 y 118).

33 Palomino, 1947: 1060-1061 y Tormo, 1985: 115. Tormo supone que fuera también de Coello la escena sobre el relicario que ocupaba el testero, aunque al principio de la descripción se queja de la oscuridad del recinto. Ponz dice que sobre el relicario había un cuadro "grande de Jordán" de San Francisco Javier bautizando indios (Ponz, 1793: 89); también José María de Eguren: "Encima del mismo relicario y tocando á la vuelta de la bóveda se vé con trabajo por la poca luz un San Francisco Javier bautizando indios, de Jordán" (EgUREN, 1847: 220). Sobre las puertas de entrada a la capilla de San Ignacio y a la sacristía, situadas a ambos lados del altar mayor, había, según Ponz, Tormo y Eguren, otros dos cuadros “apaisados” de Lucas Jordán: La conversión de San Pablo y San Francisco Javier bautizando indios. Eguren (EguREN, 1847: 221) precisa que el San Francisco Javier estaba sobre la puerta de la sacristía.

34 Archivo Moreno, IPCE, Ministerio de Educación, Cultura y Deporte, núm. de inventario 35866_B. Publicada, como obra de Donoso, por Angulo (Angulo, 1971: 315, fig. 331). José Simón-Díaz (Simón-DíAz, 1952: lámina XXXIV) publicó una fotografía del techo de la sacristía de la Capilla del Cristo de los Dolores del Hospital de la Venerable Orden Tercera de Madrid como "Bóveda de la sacristía de la iglesia, pintada por Claudio Coello y Donoso"; lo cita Sullivan, sin advertir el error (SulLivan, 1989: 241).

35 DURÁN, 1980: 76.

36 Véase nota 22.

Arch. esp. arte, LXXXVII, 347, JULIO-SEPTIEMBRE 2014, 227-244

ISSN: 0004-0428, eISSN: 1988-8511, doi: 10.3989/aearte.2014.15 
porción a sus dimensiones, eran de mayor tamaño que las de la capilla, a la vez que de contornos más simplificados, más "legibles", como los del dibujo, por lo que este también podría estar destinado al fresco de la bóveda.

Es interesante señalar al respecto que entre los bienes del pintor, inventariados a su muerte por Teodoro Ardemans y Manuel de Castro, figuraban dos cuadros de San Ignacio: uno, de media vara (40 cm. aprox.), tasado en 33 reales, y otro de "San Ignacio y Cristo", sin medidas, valorado en 100 reales $^{37}$.

El dibujo de Coello titulado San Pedro flotando entre nubes (fig. 7), aunque no conservado en la Casa de la Moneda, sino en el Museo del Prado ${ }^{38}$, por su probable relación con los frescos de la iglesia de los jesuitas, como argumentaremos a continuación, tenemos que incluirlo en este apartado.

Publicado por Sánchez Cantón como Aparición de un santo ${ }^{39}$ y por Pérez Sánchez y Sullivan como El Redentor en vuelo ${ }^{40}$, la llave que sostiene la figura con fuerza en la mano izquierda permite identificarlo como San Pedro. Su figura de perfil girada hacia la izquierda, flotando entre nubes, los voluminosos pliegues de su amplísimo manto agitados por el viento, así como la posición de la cabeza y del brazo derecho, dirigidos hacia la parte inferior, sugieren, además, que se trata de una aparición del santo.

Según Ribadeneyra, la primera aparición que tuvo San Ignacio de un santo fue la de San Pedro, "[...] quando estando desahuciado de los Medicos se le apareció este Santo Apostol"41. Ignacio, próximo a la muerte por una herida en la pierna, recibió la visita del santo en su casa de Loyola, donde, aproximándose a su lecho, le curó.

El episodio es el primero representado por el grabador flamenco Hieronymus Wierx en una serie de grabados sobre la vida del fundador de los jesuitas, publicados bajo el título Vita $B$. P. Ignatii de Loyola Fundatoris Societatis Iesu, con el santo a la izquierda, postrado en el lecho, y el apóstol a la derecha, rodeado de los rayos celestiales y con la llave en la mano izquierda, mientras que con la otra bendice al enfermo ${ }^{42}$, si bien el dibujo del Museo del Prado se aproxima más a la estampa que describe este mismo episodio en la obra Vita Beati P. Ignatii Loiolae Societatis Iesu Fundatoris, ilustrada por Jean Baptiste Barbé, posiblemente sobre dibujos de Rubens, obra que alcanzó una gran popularidad (fig. 8) ${ }^{43}$.

Si tenemos en cuenta que hasta la fecha se desconocen los temas de algunas de las escenas pintadas por Donoso y Coello en la iglesia del Colegio Imperial, se podría suponer que el dibujo estuviera destinado a una de la Aparición de San Pedro a San Ignacio. Sin embargo, el evidente parecido entre la figura del santo postrado en el lecho de la estampa de Barbé-Rubens y la del enfermo del citado fresco sobre la puerta de la sacristía, en particular el escorzo de las piernas y la mano derecha alzada mostrando la palma, nos lleva a pensar que esta escena se sustituyese más tarde por la del Milagro de San Francisco Javier -pues no parece lógico que se pintaran dos escenas de asunto y composición tan parecidos en el mismo recinto-, para la que el pintor habría aprovechado la composición general, así como la figura del enfermo -San Ignacio en un principio- y el motivo del techo de madera de la habitación en escorzo, tomado de la estampa de Wierx.

\footnotetext{
37 SulLivan, 1989: 312.

38 Número de inventario D00118. Lápiz negro, aguada parda, pluma con tinta marrón y toques de clarión sobre papel agarbanzado. $253 \times 190 \mathrm{~mm}$.

39 SÁNCHEZ CANTÓN, 1930: CDIII.

40 Pérez SÁnchez, 1972: 83-84; Sullivan, 1989: 74, D57.

41 RibadenEYra, 1790: 390.

42 Ruyven-Zeman y LeesBerg, 2004: 89.

43 BARbÉ y RuBEns, 1609: estampa 3.
} 


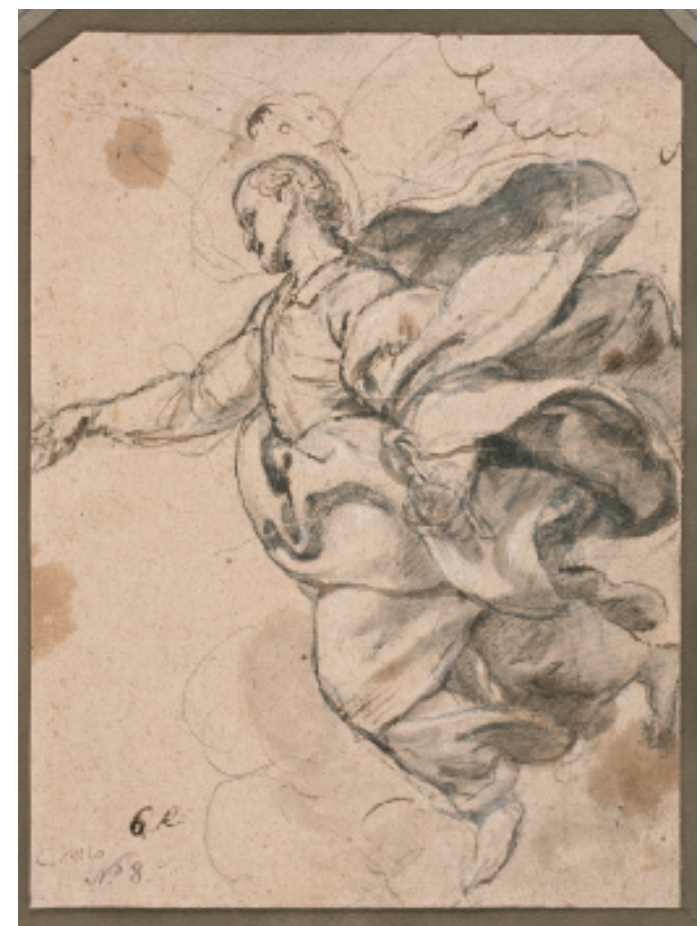

Fig. 7. Claudio Coello. San Pedro flotando entre nubes. Museo Nacional del Prado, Madrid.

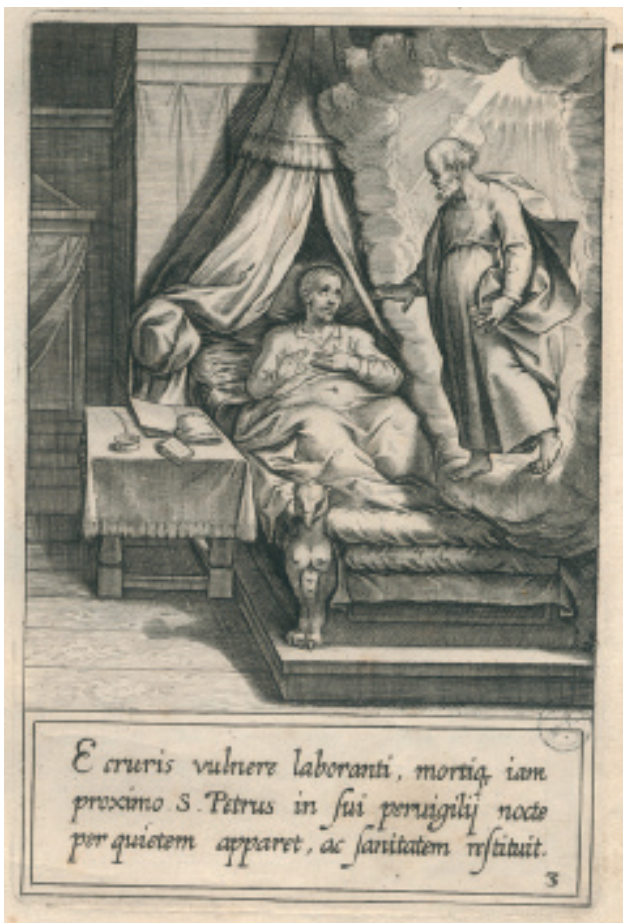

Fig. 8. Jean Baptiste Barbé. Aparición de San Pedro a San Ignacio de Loyola.

El dibujo de los Uffizi de Florencia, Dos angelitos o amorcillos, atribuido a Francisco de Herrera "El Viejo" 44 , debemos considerarlo igualmente obra de Coello (fig. 9).

Este dibujo se puede relacionar con los frescos de la iglesia del antiguo Colegio de Santo Tomás de Villanueva de Zaragoza, conocido popularmente como La Mantería ${ }^{45}$, sin duda uno de los encargos más importantes de decoración recibidos por el pintor.

La construcción del colegio y el templo, donde se trasladaría la Orden de los agustinos desde las casas de La Mantería ${ }^{46}$, comenzó en 1660 y la contratación de Coello para la decoración de la iglesia se hizo en 1683. Desde julio de ese año hasta julio de 1684 que estuvo en Zaragoza ${ }^{47}$, Coello tuvo que trabajar intensamente en estas pinturas que, antes de su lamentable deterioro, cubrían la totalidad de las seis cúpulas con linternas que cubren su planta de cruz latina ${ }^{48}$, las pechinas y arcos que las soportan, así como las paredes, si bien, según Palomino, cuando Sebastián Muñoz regresó de su estancia en Roma, fue a Zaragoza a ayudar a su maestro ${ }^{49}$. La obra se

${ }^{44}$ Inv. GDSU, cat. S. n. 10240. $197 \times 243$ mm. Lápiz negro sobre papel agarbanzado.

45 En la actualidad, iglesia de las Escolapias de San José de Calasanz.

46 Situadas en la antigua morería, sede del gremio de los artesanos manteros, a los que debe su nombre (MoNEDERO, 1999: 18).

47 Monedero, 1999: 19.

48 Todas ovoides, excepto la del crucero, de media naranja sobre un tambor octogonal.

49 Palomino, 1947: 1048-1049. Desde julio de 1684 a 1685, sabemos que Coello interrumpió su estancia en Zaragoza para realizar algunos trabajos en Madrid. 


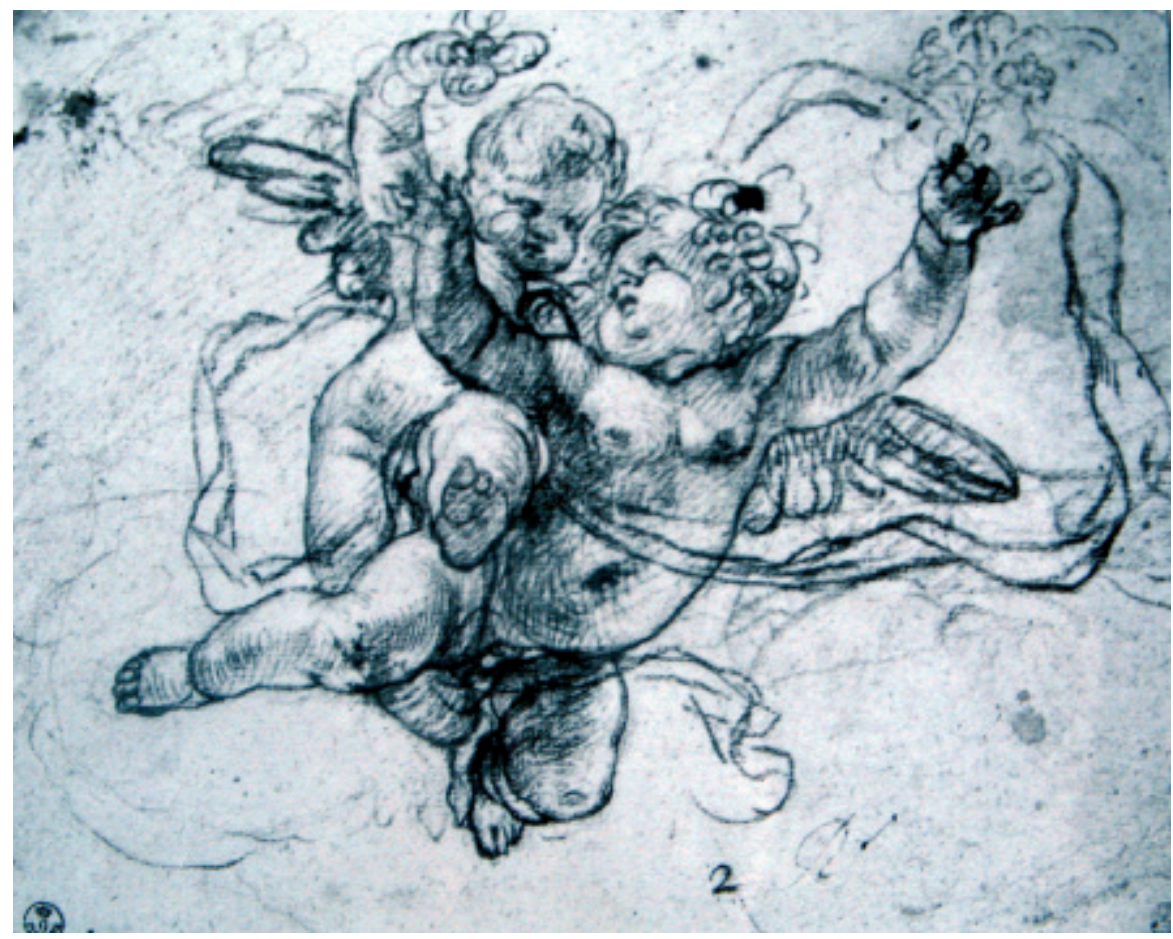

Fig. 9. Claudio Coello. Dos angelitos o amorcillos. Gabinetto Disegni e Stampe degli Uffizi, Florencia.

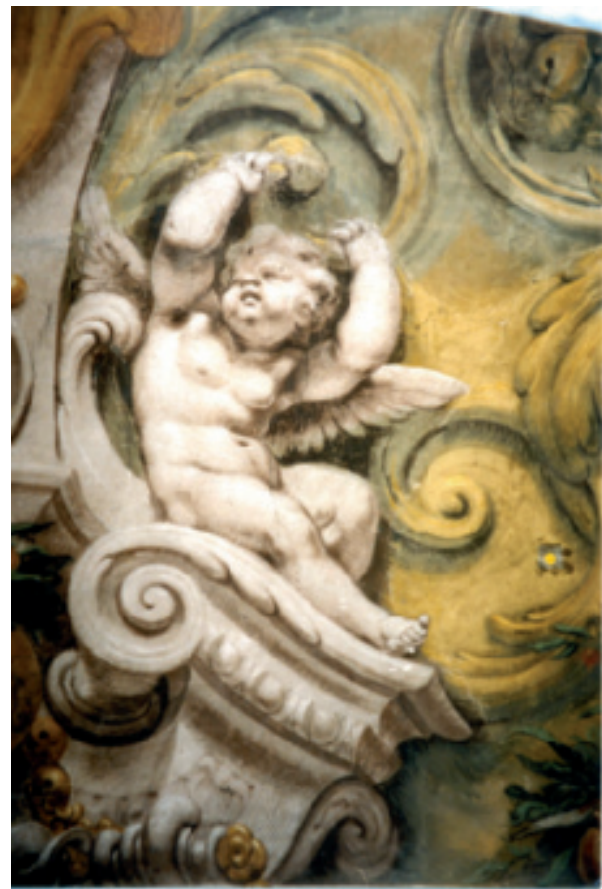

Fig. 10. Claudio Coello. Ángel niño.

Detalle de los frescos de La Mantería.

Arch. esp. arte, LXXXVII, 347, JULIO-SEPTIEMBRE 2014, 227-244 ISSN: 0004-0428, eISSN: 1988-8511, doi: 10.3989/aearte.2014.15 
terminó en 1685, como acredita la inscripción en la pintura del presbiterio: "Claudius Coello fat Pic. Reg. anno 1685", y se inauguró en 1686. El pintor, satisfecho sin duda del resultado de tan importante encargo, se autorretrató junto a la firma. Seguramente por los mismos motivos, incluyó el retrato de su discípulo formando pareja en el lado opuesto del mismo fresco, imagen de sumo interés, por cuanto, de momento, parece rechazar la catalogación de un retrato del Museo del Prado como un autorretrato de Sebastián Muñoz ${ }^{50}$.

El programa iconográfico gira alrededor de la apoteosis de Santo Tomás de Villanueva, agustino canonizado en 1658, representada en la cúpula principal, lograda mediante sus virtudes y méritos, a través de la intercesión de los santos agustinos, de la Virgen y merced a la Pasión de Cristo. Escenas de la vida del santo, alegorías de sus cualidades, las cuatro partes del mundo, símbolos de la Virgen, de la Pasión, ángeles niños, jarrones con flores, inscripciones... decoran la totalidad de las cubiertas.

Diversas causas, desde la técnica utilizada por el propio Coello, agresiones sufridas a lo largo del tiempo y posteriores y nefastas restauraciones ${ }^{51}$, ocasionaron la pérdida de gran parte de uno de los conjuntos más importantes del barroco decorativo español.

El último proceso de restauración, iniciado en 1999 por la Escuela Taller "La Mantería", permite comprobar la variedad de ángeles niños pintados, o al menos diseñados por Coello en variadas posiciones, sosteniendo diferentes objetos con sus manos..., de los que, por su enorme parecido con los representados en este dibujo, vamos a señalar uno de los que decoran la cúpula del lado de la Epístola, dedicada a la Pasión ${ }^{52}$ (fig. 10).

\section{Pinturas}

En el ático del retablo de La Resurrección de la parroquia de San Salvador de Leganés (Madrid), colateral del altar mayor, se conserva un cuadro de La Transfiguración ${ }^{53}$ que, pese a no estar firmado ni documentado, por composición, técnica y estilo puede ser atribuido a Claudio Coello (fig. 11).

El retablo y su pareja, dedicado a San José, se contrataron hacia 1717 con el arquitecto y escultor José Benito de Churriguera, aunque, a causa de un pleito con el párroco, no se construyeron hasta 1720 aproximadamente ${ }^{54}$. Ambos constan de banco, un único cuerpo, que aloja una hornacina central flanqueada por dos pares de columnas salomónicas, y ático decorado con un lienzo ovalado. Churriguera, quien anteriormente había realizado el retablo mayor de la iglesia, fue también el autor de las imágenes de Cristo resucitado y San José de las hornacinas ${ }^{55}$.

La escena de La Transfiguración es una ilustración bastante literal los textos de los Evange$\operatorname{lios}^{56}$. En la parte superior aparece Cristo resplandeciente, flanqueado por las figuras de Moisés y Elías, con quienes parece dialogar. Más abajo, los Apóstoles Juan, a la derecha, Pedro, en el

\footnotetext{
50 Cat. núm. P00957. MartínEZ RiPoll, 1985: 344-345, fig. 14; UrReA, 1996: 74. Urrea lo consideraba de calidad superior a los retratos firmados y fechados por el pintor.

51 Véase SENSERrich, 2000: 11 y ss.

52 Nuestro más sincero agradecimiento a María Jesús Boned, quien amablemente nos ha facilitado esta fotografía.

53 Dimensiones difíciles de obtener. Aproximadamente, $2 \mathrm{~m}$ de alto.

54 Rodríguez G. DE Ceballos, 1972: 30-32.

55 Sustituidas más tarde por una del Salvador, destruida durante la Guerra Civil, y otra moderna de San José. El retablo de La Resurrección lo preside en la actualidad una imagen moderna de La Virgen del Carmen.

56 Mt, 17, 1-13; Mc, 9, 1-12 y Lc, 9, 28-36.
}

Arch. esp. arte, LXXXVII, 347, JULIO-SEPTIEMBRE 2014, 227-244

ISSN: 0004-0428, eISSN: 1988-8511, doi: 10.3989/aearte.2014.15 


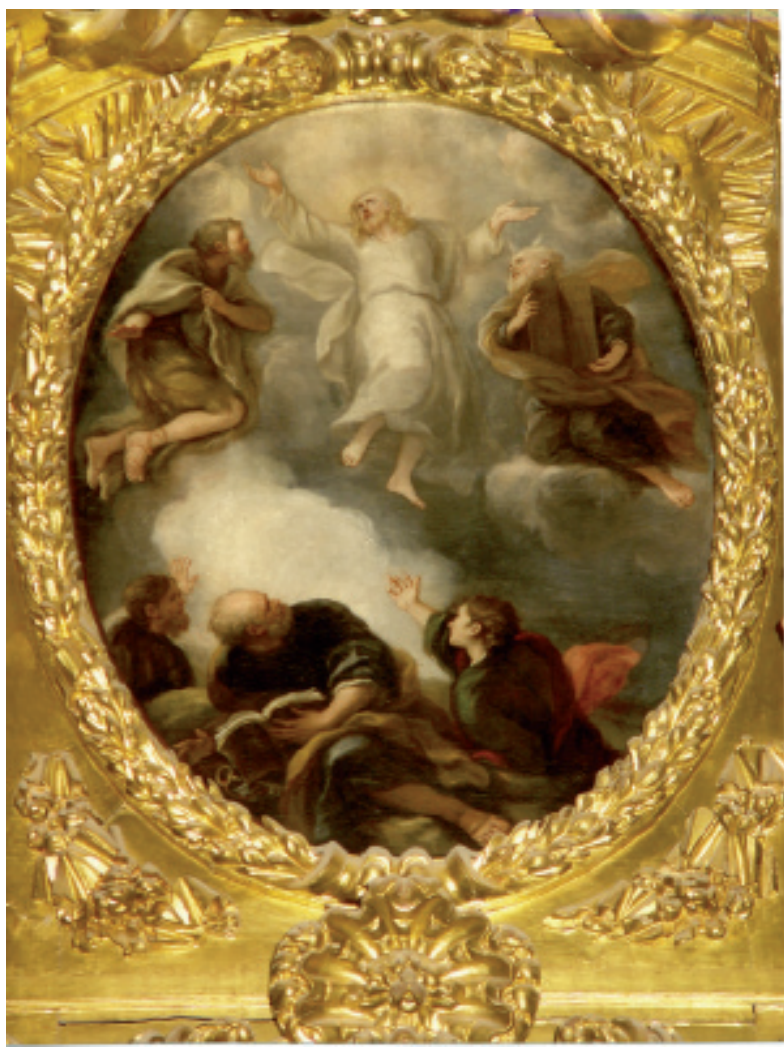

Fig. 11. Claudio Coello. La Transfiguración. Parroquia de San Salvador, Leganés. Foto: Manuel Quintana. centro, con las llaves y un libro abierto ${ }^{57}$, y Santiago, gesticulan atemorizados; sobre ellos, la gran nube luminosa que les cubrió con su sombra y de la que salió una voz que dijo: "Este es mi Hijo amado, en quien me complazco: escuchadle" 58 . La obra debe de corresponder a los últimos años de la actividad de Coello, en torno a 1691-1693, por las evidentes coincidencias de estilo y factura con el cuadro de La lapidación de San Esteban del retablo mayor de la iglesia del convento de San Esteban de Salamanca ${ }^{59}$, firmado y fechado en 1693.

La presencia del lienzo de Coello en un retablo contratado más de veinte años después de su muerte, así como el hecho de que repita el tema de $L a$ Transfiguración del cuadro que preside el retablo mayor, firmado y fechado en 1702 por el pintor veneciano Francesco Leonardoni ${ }^{60}$, algo un tanto inusual, se podría explicar por la relación personal y laboral existente entre Claudio Coello y José de Churriguera.

El pintor conocía al joven escultor y arquitecto a través de su relación laboral con el ensamblador José Ratés ${ }^{61}$, quien en 1679, a la muerte del padre, José Simón de Churriguera, adoptó a sus hijos ${ }^{62}$. Juntos trabajaron en el retablo mayor de la iglesia del convento de dominicos de San Esteban de Salamanca. La arquitectura se había contratado con Churriguera por el prior del convento, fray Gonzalo Mateos, el 26 de enero de $1692^{63}$, seguramente por recomendación de Coello, en esas fechas pintor de cámara, con quien el dominico fray Pedro Matilla, confesor de Carlos II desde 1683 y persona influyente en

57 Pedro aparece como testigo del cumplimiento de las profecías del Antiguo Testamento: "Os hemos dado a conocer el poder y la Venida de Nuestro Señor Jesucristo, no siguiendo fábulas ingeniosas, sino después de haber visto con nuestros propios ojos su majestad. Porque recibió de Dios Padre honor y gloria, cuando la sublime Gloria le dirigió esta voz: 'Este es mi hijo muy amado en quien me complazco.' Nosotros mismos escuchamos esta voz, venida del cielo, estando con él en el monte santo". (2Pedro, 1, 16-18).

$58 \mathrm{Mt}, 17,5$.

59 Rodríguez G. De Ceballos, 1971: 19-21, lám. 1; Sullivan, 1989: 223, P99.

60 Rodríguez G. De Ceballos, 1972: 26. Sobre el pintor, véanse PAlomino, 1947: 1131-1132 y CEÁn, 1800: 20.

${ }^{61}$ Coello y Ratés trabajaron juntos en el retablo mayor de la iglesia de San Juan Evangelista de Torrejón de Ardoz (1674-1675), en el retablo de San Juan Bautista de la Iglesia de San Nicolás de Madrid (1678) y en las decoraciones efímeras erigidas con motivo de la entrada en la corte de María Luisa de Orleans (1680).

62 Rodríguez G. De Ceballos, 1971: 13.

63 Rodríguez G. DE Ceballos, 1971: 20.

Arch. esp. arte, LXXXVII, 347, JULIO-SEPTIEMBRE 2014, 227-244 ISSN: 0004-0428, eISSN: 1988-8511, doi: 10.3989/aearte.2014.15 
palacio, había concertado el cuadro del Martirio de San Esteban para el ático del retablo ${ }^{64}$. Esto explicaría que en una de las cláusulas del contrato se indique que el pintor debía supervisar el proyecto, de tal forma que "se a de añadir a la traza lo que dijere que le falta de adornos para mayor perfezión así en las gradas como en todo lo demás que condujere a su mayor adorno y hermosura" 65 .

Las similitudes entre los retablos colaterales de San Esteban, en particular el del lado de la Epístola, y los de la parroquia de Leganés, podrían hacernos suponer que Coello y Churriguera se encargaron también de su traza. Al fallecer el pintor en 1693, únicamente dejaría terminado el lienzo de uno de ellos, La Transfiguración. La construcción, por motivos que desconocemos, no la realizó José, sino su hermano Joaquín, en $1702^{66}$, "quizá sobre dibujo dejado por su hermano mayor, pues se parece intensamente a los colaterales que éste hizo en Leganés"67. Prosiguiendo con nuestra hipótesis, cuando José Benito contrató los colaterales de Leganés, hacia 1717, retomaría la traza de los de Salamanca y reutilizaría el lienzo de Coello, seguramente en su

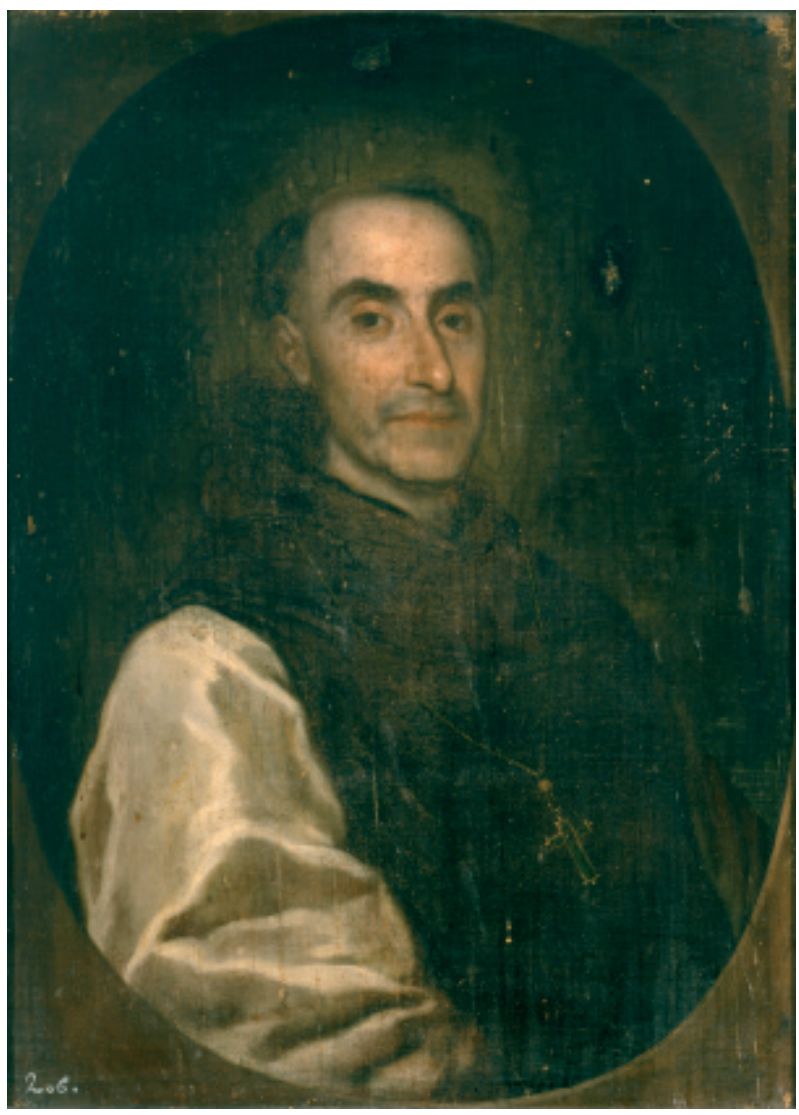

Fig. 12. Claudio Coello. Retrato de fray Alonso de Talavera. Real Monasterio de San Lorenzo de El Escorial. poder, para decorar el ático del retablo dedicado a Cristo resucitado, con la talla de la misma advocación realizada por el mismo Churriguera en la hornacina ${ }^{68}$.

Nuestra última aportación al catálogo de Claudio Coello es el retrato de medio cuerpo de Fray Alonso de Talavera (fig. 12) ${ }^{69}$, XXIX prior de la comunidad de monjes jerónimos del Monasterio del Escorial, encargada de su cuidado desde su fundación por Felipe II (1567) hasta 1835, conservado en las dependencias de los padres agustinos del monasterio.

El retratado se muestra dentro de un marco ovalado fingido, girado hacia su izquierda y con la mirada dirigida hacia el espectador. Viste el hábito blanco de la orden, en el que destaca la

${ }^{64}$ El pintor cobró, por la que se supone hasta ahora su última obra, 6.000 reales (Sullivan, 1989: 223).

65 Rodríguez G. DE Ceballos, 1971: 20.

${ }^{66}$ El del lado del Evangelio lo empezó en 1703 Pedro Bachiller, pero Joaquín lo desmontó y reformó, igualándolo con el otro (Rodríguez G. De Ceballos, 1971: 50, núm. 8).

67 Rodríguez G. De Ceballos, 1971: 50, núm. 8.

${ }^{68}$ El lienzo del retablo gemelo, Los desposorios de la Virgen, es de otra mano, contemporáneo del retablo.

${ }^{69}$ Número de inventario 10035191. Óleo sobre lienzo. 82,5 × 62,5 cm. En el reverso, una hoja de papel pegada con los datos más destacados de la vida del prior, escritos a pluma con caligrafía del siglo XIX. 
abultada manga, con el escapulario marrón, sobre el que luce una cruz que cuelga de una cadena. En el ángulo inferior izquierdo destaca en blanco el número 206, correspondiente al catálogo de los cuadros del monasterio realizado por Poleró en $1857^{70}$.

El futuro prior nació en La Puebla Nueva (Toledo) hacia 1640. Tras su formación en el seminario de San Lorenzo, donde estudió retórica y gramática, tomó el hábito en el monasterio el 11 de octubre de 1656. Su humildad, dotes literarias e interés por los estudios de arte y teología, le llevaron a ocupar diversas cátedras de teología, así como los cargos de calificador de la Suprema del Santo Oficio, predicador del rey, visitador general de Castilla, presidente del capítulo, y otros. En 1690 fue propuesto, entre otros, a Carlos II para el cargo de prior del monasterio. El monarca, que solía asistir a sus funciones públicas cuando era su predicador, no dudó en nombrarle prior, puesto que desempeño desde mayo de 1690 hasta mayo de 1696, cuando, la estimación que el monarca y su esposa, Mariana de Neoburgo, sentían por fray Alonso, favoreció su nombramiento de obispo de Cádiz, donde fallecería el 18 de diciembre de $1714^{71}$.

Pese al deterioro del lienzo, impresiona el rostro por la calidad de la factura, el naturalismo y la penetración psicológica del personaje, de mirada viva e inteligente, que deja entrever su espiritualidad, bondad y simpatía. Del resto del cuadro destaca la abultada manga del hábito, en la que se reproducen con destreza los pliegues y la calidad de la lujosa tela, impropia de los hábitos jerónimos, lo que nos lleva a pensar en una licencia del pintor a fin de constatar la importancia del personaje.

La contemplación directa del cuadro confirma lo que ya intuíamos en una fotografía recien$t^{72}$ : que su formato original era rectangular, añadiéndose el marco fingido en fecha posterior, como indica la manga -visible a través del marco-, pintada hasta el borde del lienzo, y que la cruz sobre el escapulario marrón, sin concluir o muy perdido, está igualmente añadida después. Por último, en la parte derecha, además de parte de la manga izquierda, muy oscurecida, se aprecia una barandilla de balaustres que se abre a un fondo de paisaje, sin duda, una vista desde el monasterio.

La calidad de las partes señaladas, la técnica, la factura y el hecho de que fray Alonso ocupara el puesto de prior del monasterio en 1690, fechas en las que Claudio Coello se encontraba trabajando en el gran cuadro de La Sagrada Forma para la sacristía de la iglesia ${ }^{73}$, nos lleva a considerarlo una obra del pintor de cámara del monarca, confiando en que su futura restauración lo confirme.

\section{BIBLIOGRAFÍA}

Angulo Íñiguez, Diego, "Dibujos españoles en el Museo de los Uffizi (II)", Archivo Español de Arte y Arqueología, núm. 10, 1928, pp. 45-55.

Angulo Íniguez, Diego, Ars Hispaniae, Historia Universal del Arte Hispánico, Volumen Décimoquinto, Pintura del siglo XVII, Madrid, Ed. Plus Ultra, 1971.

\footnotetext{
70 Poleró, 1857: 68.

${ }^{71}$ Aunque está enterrado en su diócesis, en las Actas sepulcrales del Monasterio se incluye su nombre y su vida en la sepultura 1. a de las cuatro destinadas a los priores, en el claustro de la Iglesia vieja (PASTOR GómEZ-CoRnEJO, 2001: 198-200).

${ }^{72}$ Que agradecemos a Carmen García-Frías, conservadora de Patrimonio Nacional.

73 Coello empezó a trabajar en el gran lienzo a la muerte de Francisco Rizi (1685), y lo terminó antes del 18 de octubre de 1690, cuando se le comunicó a Carlos II. El 29, el rey presidió la solemne procesión organizada para trasladar la Sagrada Forma, portada bajo palio por fray Alonso de Talavera, confirmado como prior el 5 de mayo de ese mismo año, e inaugurar el retablo y el camarín (MediavilLa MARTín, 2001: 29 y 37-38).
} 
Angulo Íñiguez, Diego y Pérez Sánchez, Alfonso E., Historia de la Pintura Española, Escuela Madrileña del segundo tercio del siglo XVII, Madrid, Consejo Superior de Investigaciones Científicas, Instituto Diego Velázquez, 1983.

Aterido, Ángel, "Idea y contexto de una talla sevillana: La Capilla del Cristo del Colegio Imperial de Madrid", Archivo Hispalense, tomo 81, núm. 246, 1998, pp. 201-238.

Aterido, Ángel, "Del homenaje de los discípulos y una sombra velazqueña: Francisco Rizi y Claudio Coello en La Adoración de la Sagrada Forma de Gorkum", en In Sapientia libertas. Escritos en homenaje al profesor Alfonso E. Pérez Sánchez, Madrid, Museo del Prado-Fundación Focus Abengoa, 2007, pp. 507512.

Barbé, Jean Baptiste; Rubens, Peter Paul, Vita Beati P. Ignatii Loiolae Societatis Iesu Fundatoris, Roma, 1609. Existe edición facsímil, Vida de San Ignacio de Loyola en imágenes, ed. fac. y estudio preliminar de Antonio M. Navas Gutiérrez, Servicio de publicaciones de la Universidad de Granada, Facultad de Teología, 1993.

Brown, Jonathan (comisario), Pintura de los Reinos. Identidades compartidas en el mundo hispánico, cat. exp., Madrid, Palacio Real de Madrid, Museo Nacional del Prado, 2010.

Ceán Bermúdez, Agustín, Diccionario Histórico de los más ilustres profesores de Las Bellas Artes en Espa$\tilde{n} a$, tomo tercero, Madrid, Real Academia de San Fernando, 1800.

Colorado, Alberto, La iglesia del convento de la Encarnación Benita, más conocido como convento de San Plácido, Madrid, 1992.

Durán González-Meneses, Reyes, Catálogo de los dibujos de los siglos XVI y XVII de la colección del Museo de la Casa de la Moneda, Madrid, Servicio de publicaciones del Ministerio de Hacienda, 1980.

Eguren, José María de, "San Isidro el Real. (Conclusión)", en Semanario Pintoresco Español, núm. 28, 117-1847, pp. 218-221.

Gaya Nuño, Juan Antonio, Claudio Coello, Madrid, Instituto Diego Velázquez, del Consejo Superior de Investigaciones Científicas, 1957.

Gómez Jara, Jesús, "Dos pinturas de Claudio Coello en el Convento de Agustinas Recoletas de La Calzada de Oropesa", Anales toledanos, núm. 43, Diputación Provincial de Toledo, 2007, pp. 151-164.

Gutiérrez Pastor, Ismael, "Novedades sobre Claudio Coello, con algunas cuestiones iconográficas y compositivas", Anuario del Departamento de Historia y Teoría del Arte, Universidad Autónoma de Madrid, vol. XV, 2003, pp. 125-145.

Lamas Delgado, Eduardo, "Un dibujo de Claudio Coello para un cuadro de Luca Giordano", Anuario del Departamento de Historia y Teoría del Arte, Universidad Autónoma de Madrid, vol. XVIII, 2006, pp. 97-105.

Martínez Ripoll, Antonio, "Sebastián Muñoz, Pintor de María Luisa de Orleans”, Archivo Español de Arte, núm. 232, 1985, pp. 332-350.

Mediavilla Martín, Benito, La Sagrada Forma del Escorial, Madrid, Real Monasterio de El Escorial, Ediciones Escurialenses, 2001.

Monedero Granados, Cristina, "La Iglesia de Santo Tomás de Villanueva", en La Mantería, Revista de la Escuela Taller, núm. 1, Zaragoza, Gobierno de Aragón, Departamento de Cultura y Turismo, 1999, pp. 17-21.

Nicolau Castro, Juan, "El retablo mayor de la parroquial de Calzada de Oropesa (Toledo) y sus lienzos de Claudio Coello", Boletín del Seminario de Estudios de Arte y Arqueología (BSAA), tomo 54, Universidad de Valladolid, 1988, pp. 442-451.

Palomino de Castro y Velasco, Antonio, El museo pictórico y escala óptica, Madrid, M. Aguilar (editor), 1947.

Pastor Gómez-Cornejo, Fernando, Las memorias sepulcrales de los Jerónimos de San Lorenzo del Escorial, San Lorenzo del Escorial, Ediciones Escurialenses, 2001.

Pérez Hernández, Manuel, "Patrimonio disperso de la Universidad de Salamanca: dos lienzos de Claudio Coello y el calvario del primitivo retablo", De Arte, núm. 10, 2011, pp. 117-128.

Pérez Sánchez, Alfonso E., Museo del Prado. Catálogo de dibujos I. Dibujos españoles. Siglos XV-XVII, Madrid, 1972.

Pérez Sánchez, Alfonso E., "En torno a Claudio Coello”, Archivo Español de Arte, núm. 250, 1990, pp. 129155.

Arch. esp. arte, LXXXVII, 347, JULIO-SEPTIEMBRE 2014, 227-244

ISSN: 0004-0428, eISSN: 1988-8511, doi: 10.3989/aearte.2014.15 
Poleró y Toledo, Vicente, Catálogo de los cuadros del Real Monasterio de San Lorenzo, llamado del Escorial, en el que se comprenden los del Real Palacio, Casino del Príncipe y Capilla de la Fresneda, Madrid, Imprenta de Tejado, 1857.

Ponz, Antonio, Viage de España, en que se da noticia de la cosas más apreciables, y dignas de saberse, que hay en ella, tomo quinto, Madrid, 1793.

Réau, L., Iconografia del arte cristiano, tomo 2, vol. 3, Barcelona, Ediciones del Serbal, 2001.

Ribadeneyra, Pedro de, Flos Sanctorum de las Vidas de los Santos, Tomo II, Barcelona, Imprenta de los Consortes Sierra, Olivér, y Martí, 1790.

Rodríguez G. de Ceballos, Alfonso, "El Colegio Imperial de Madrid. Historia de su construcción”, Miscelánea Comillas, vol. 28, núm. 54, 1970, pp. 407-444.

Rodríguez G. de Ceballos, Alfonso, Los Churriguera, Madrid, Instituto Diego Velázquez, del Consejo Superior de Investigaciones Científicas, 1971.

Rodríguez G. de Ceballos, Alfonso, "Los retablos de la parroquia de San Salvador de Leganés", Archivo Español de Arte, núm. 177, 1972, pp. 23-32.

Ruyven-Zeman, Zsuzsanna y Leesberg, Marjolein, Hollstein's Dutch \& Flemish etchings, engravings and woodcuts, 1450-1700, The Wierix family, part VII, vol. LXV, Rotterdam, Sound \& Vision Publishers, 2004.

Sánchez Cantón, Francisco Javier, Dibujos españoles, vol. V, Madrid, Ministerio de Instrucción Pública y Bellas Artes, 1930.

Senserrich Espuñes, Rosa, "Examen organoléptico y estado de conservación de las pinturas murales de 'La Mantería", en La Mantería, Revista de la Escuela Taller, núm. 2, Zaragoza, Gobierno de Aragón, Departamento de Cultura y Turismo, 2000, pp. 7-21.

Simón-Díaz, José, Historia del Colegio Imperial de Madrid, Tomo I, Madrid, Consejo Superior de Investigaciones Científicas, Instituto de Estudios Madrileños, 1952.

Sullivan, Edward J., Claudio Coello y la pintura barroca madrileña, Madrid, Editorial Nerea, 1989, edición en español de Baroque Painting in Madrid. The Contribution of Claudio Coello, with a Catalogue Raisonné of his Works, Columbia, University of Missouri Press, 1986.

Tormo, Elías, Las Iglesias de Madrid, reedición de los dos fascículos publicados en 1927, Instituto de España, 1985.

Urrea, Jesús (comisario), Pintores del reinado de Carlos II, cat. exp., Madrid, Museo del Prado, 1996.

Véliz Bomford, Zahira, "Una composición temprana atribuida a Claudio Coello", en In Sapientia libertas. Escritos en homenaje al profesor Alfonso E. Pérez Sánchez, Madrid, Museo del Prado-Fundación Focus Abengoa, 2007, pp. 493-497.

Zapata Fernández de la Hoz, Teresa, "Un tema de la Antigüedad clásica en un dibujo de Claudio Coello", en In Sapientia libertas. Escritos en homenaje al profesor Alfonso E. Pérez Sánchez, Madrid, Museo del Prado-Fundación Focus Abengoa, 2007, pp. 498-506.

Fecha de recepción: 17-VII-2013

Fecha de aceptación: 10-III-2014 